\title{
Inland Water Survey in Great Britain
}

$\mathrm{T}^{\mathrm{T}}$ HE second annual report* (1936-37) of the Inland Water Survey under the Ministry of Health and the Scottish Office continues the story of the progress of the Survey since the date of the previous report. It points out the magnitude of the undertaking and the considerable amount of pre. liminary work which has been found necessary. The replies to the questionnaire circulated at the outset of investigations showed that relatively little of the varied mass of information in existence was suitable for the purposes of the Survey, and that not only were improvements necessary in the methods in vogue for gauging and recording levels in rivers and streams, but also that a large number of additional gauging stations was required. During the period under review, the efforts of the Committee and its officers have been directed towards the introduction of better methods of survey and to the examination and rearrangement of existing records suitable for publication in a form which would serve as a model for future investigations.

Emphasis is rightly laid on the importance of the functions of the new catchment boards in obtaining a full knowledge of river flows and their variations. In order to assist the catchment boards and others co-operating in the same direction, an instructional memorandum on the water survey of a river system was prepared and published in October, 1936. It is added that during the year an increasing interest has been shown in the Survey, but the comment is made that this interest tends to manifest itself only in regard to those parts of a record which are of most use to the persons or bodies concerned. This is, of course, perfectly natural; but it is obviously insufficient for the purposes of a complete survey. Thus the catchment boards show a disposition to limit their observations to periods of high discharge,

* Ministry of Health and Scottish Office. Inland Water Survey Committee: Second Annual Report, 1936-37. Pp. 26. (London: H.M. Stationery Office, 1937.) 6d. net. when flooding is liable to occur, and to ignore periods of relatively low discharge. But periods of low discharge are important for pollution prevention and to fishery authorities, and fundamentally so to water undertakers, so that a survey must be comprehensive in its records if it is to be of service to all classes of the community.

Underground water measurement is a branch of the work of the Survey which is being carried on with the assistance of the Geological Survey, and a tribute is paid to the late Dr. Bernard Smith, director of the Geological Survey, who took a great interest in the Inland Water Survey and acted as one of its assessors.

Assistance in hydrographical field work is being given by outside bodies and individuals ; in particular, by schoolboys under the direction of their headmasters and geography masters. Their services are being utilized in the location and measurement of wells.

The examination of certain river basins in detail, begun in the previous year, has been continued, and observations of a preliminary character have been made during the twelve months in regard to the Ness Basin, the Tay, Ouse (Yorkshire), Severn, Dee (Cheshire), Irvine, Clyde and Kelvin. The results of these investigations are set out in the report and a well-merited acknowledgement is made of the pioneer work of Captain W. N. McClean in founding and directing at his own expense the organization known as River Flow Records, which has carried out discharge measurements in the Ness Basin and elsewhere during the past eight years.

The investigations made and collected from various sources are being "converted, amplified, corrected, extended and consolidated". It is announced that a selection, dealing with the results from twentyeight gauging stations in respect of fourteen river basins in Great Britain, will shortly be published.

Brysson Cunningham.

\section{Research Grants of the American Academy of Arts and Sciences}

NCOME from the Permanent Science Fund
of the American Academy of Arts and Sciences,
according to agreement and declaration of trust, shall
be applied to such scientific research as shall be
selected . . in "such sciences as Mathematics,
Physics, Chemistry, Astronomy, Geology and Geo-
graphy, Zoology, Botany, Anthropology, Psychology,
Sociology and Economy, History and Philology,
Engineering, Medicine and Surgery, Agriculture,
Manufacturing and Commerce, Education, and any
other science of any nature or description whether
or not now known or now recognized as scientific;
and may be applied to or through public or private
associations, societies, or institutions, whether incor.
porated or not, or through one or more individuals."
Applications for grants under this indenture are considered by a committee of the Academy on stated dates only. The next such meeting will be to consider applications received in proper order on blank forms furnished by the committee on March 1, 1938. Correspondence, including requests for application forms, should be addressed to the chairman of the Committee on the Permanent Science Fund, Prof. John W. M. Bunker, Massachusetts Institute of Technology, Cambridge, Massachusetts.

Grants-in-aid from this fund were voted by the Academy on November 10, 1937, as follows :

Prof. Charles Chupp, Cornell University, 400 dollars, to aid in finishing a monograph of the fungus genus Cercospora. 
Dr. Willi M. Cohn, research lecturer, University of California, 150 dollars to be used in printing, in the Astrophysical Journal, the results obtained on the polarization of the solar corona in the 1932 and 1934 eclipse expeditions.

Prof. Ada R. Hall and Helen W. Kaan, Wellesley College, 59 dollars, to assist in a histological investigation of the development of thyroid glands in rat embryos.

Prof. Robert S. Harris, Massachusetts Institute of Technology, 300 dollars, for the purchase of mothers' milk, to be used in an investigation of $(a)$ the chemistry of the casein; $(b)$ the antirachitic properties.

Dr. Francis R. Hunter, Rhode Island State College, 250 dollars, towards the purchase of a Barcroft-Warburg micro-respirometer, to be used in a comparative study of respiration and permeability.

Prof. Walter Landauer, Storrs Agricultural Experiment Station, 150 dollars, for the purchase of an analytical balance to be used in connexion with a quantitative study of growth in lethal embryos of creeper and Cornish fowl.

Dr. Clarence C. Little, director of the Roscoe B. Jackson Memorial Laboratory, 1,000 dollars, to be used to study the incidence of tumours and other growth abnormalities in a species cross in mice.

Dr. Karl E. Mason, Vanderbilt University School of Medicine, 500 dollars, for technical assistance in the development and standardization of trustworthy methods for the routine assay of food substances for their vitamin $\mathrm{E}$ content.

Prof. Arthur F. Scott, Reed College, 500 dollars, for the purchase of apparatus to be used in determinations of the atomic weights of beryllium and bismuth.

Drs. Kurt G. Stern and Abraham White, Yale University School of Medicine, 400 dollars, to be used for the construction of equipment for the study of the homogeneity and certain physical properties of highly purified protein preparations and protein derivatives.

Dr. John H. Welsh, Harvard University, 200 dollars, to enable him, during his sabbatical leave, to visit the laboratories of Prof. Koller at Kiel, and Prof. Hanström at liund.

Prof. William F. Windle, Northwestern University Medical School, 500 dollars, for employing the services of a trained laboratory assistant in a study of neurological factors in the development of fotal respiration, and other general problems of fœtal behaviour.

\section{Foundations of Terrestrial Life: The Soil and the Green Plant*}

$\mathrm{T}$ HE ideas which I want to put forward may perhaps be indicated best by telling how and by what slow stages they grew up in my mind. A long time ago the late Prof. Gamble and I spent a very long time trying to find out how the green cells which give colour to the marine worm Convoluta Roscoffenis get into the body of the animal, how they manage to increase and multiply there, and what is the impetus which drives them into the association. The conclusion which we reached as to the significance of the association between Convoluta and its green cells is nitrogen hunger. The symbiosis is only one of innumerable examples of the universal fact that the world of plants suffers, and has always suffered, from an insufficiency of nitrogen.

A good many years later, just after the Great War, the late Lord Melchett (then Sir Alfred Mond) and I spent a lot of time trying to improve the farm land surrounding Melchet Court. There was plenty of scope on soil which when it was not gravelly was clayey, and even when it wasn't was panned. Among other things, the effects of nitrogen and other fertilizers were tried on the grass land, and met with a success which was astonishing. In those days nitrogen was generally supposed to be bad for grass land. It was thus proved, however, to be wonderfully good, and that even when the poor grass land was supplied with a complete fertilizer and limed as well, the addition of more nitrogen produced more grass.

About that time, Sir Alfred Mond was taking a practical interest in the synthetic manufacture of ammonia, and there is no doubt that the results of our experiments on the value of nitrogen on grassland had something to do with his asking me

* The argument introduced in a series of three lectures delivered at the Royal Institution on November 30 and December 7 and 14. to give up an Oxford professorship and become director of agricultural research in the company which had been formed recently to develop the process at Billingham. The Research Station at Jeallot's Hill was established, and with the aid of colleagues I laid down and conducted a world-wide programme of experiments on the effects of nitrogen and other fertilizers on grass and arable land.

The next step in the development of my ideas was reached when on a visit to Ireland I was shown by one of our staff the almost incredibly swift response to nitrogen that rough, boggy, hillside grazings were making. Sedges and weeds of all kinds with scarcely any grass or clover began to disappear in a season or two, to be replaced by grasses and clovers, with the result that where before no grass grew there was soon good grazing.

The final step was reached in the course of feeding experiments with dried grass made at Jeallot's Hill. The results of the experiments showed that the winter milk of cows fed on a liberal ration of dried grass produced a butter with all the virtues of summer butter in it.

Looking back along this long, tortuous road, I find it difficult to believe that anybody could have been so slow to reach the conclusion to which it leads, or could require so much material on which to base a hypothesis which ought to have jumped to the mind long ago. The hypothesis is that the health and strength of people and their evolution, and the permanence of human societies depend on the soil and the green plant. The conclusions are that if the world has got on so well as it has with a halfstarved vegetation and a hungry soil, how much better might it not get on when these deficiencies are discovered and made good.

F. KEEBLE. 